\title{
Evaluation of Hydrogeological Quality of Various Implementations of Riga City Water Supply System
}

\section{Rīgas pilsētas pazemes ūdensgūtvju izmantošanas optimizācijas variantu hidroǵeologiiskais izvērtējums}

\author{
Inta Lāce ${ }^{1}$, Kaspars Krauklis ${ }^{2}$, Aivars Spalviniš $\check{s}^{3}$, Juris Laicāns ${ }^{4}$ \\ ${ }^{1-3}$ Rīgas Tehniskā universitāte, Latvija, ${ }^{4}$ SIA Aqua-Brambis
}

\begin{abstract}
Kopsavilkums - Rīgas pilsētu ar dzeramo ūdeni apgādā pazemes ūdensgūtvju komplekss Baltezers, Zakumuiža, Remberği un Daugavas upe kā virszemes ūdensgūtve. Šobrīd (2016. g.) abas ūdensgūtves neizmanto pat pusi no to ražības, un tāpēc Rīgai būtu lietderīgi izmantot tikai pazemes ūdeni ( 122 tūkst. $\mathbf{m}^{3}$ / dnn), jo upes ūdens nav kvalitatīvs, tāpēc tā attīrīšana ir dārga. Rīgas Tehniskās universitātes speciālisti, izmantojot pazemes ūdensgūtvju kompleksa hidroğeologisko modeli, ir apstiprinājuši, ka Rīgas pilsētai nākotnē nav nepieciešama virszemes ūdensgūtve. Pētījums veikts kā SIA $A Q U A-B R A M B I S$ uzdevums, kurš paredzēja piecu Rīgas pilsētas pazemes ūdensgūtvju izmantošanas variantu hidroǵeoloǵisko izvērtējumu (pazemes ūdens līmeṇu izmaiṇas, laika apstākḷu ietekme, pazemes ūdens plūsmu aprēḳini u. c.). Rakstā nav analizētas ūdensgūtvju un ūdens sadales tīklu rekonstrukciju izmaksas.
\end{abstract}

Atšēgas vārdi - Dziḷumsūkṇi, hidroğeoloğiskais modelis, pazemes ūdensgūtves, sifona tipa ūdensgūtve.

\section{IEVADS}

Rīgas pilsētas centralizēto ūdensapgādi nodrošina SIA Rìgas üdens. 2015. gadā pilsētas vidējais diennakts ūdens patērinšs bija $124700 \mathrm{~m}^{3} / \mathrm{dnn}$ [1]. Šo ūdens daudzumu nodrošināja pazemes ūdensgūtves $\left(61100 \mathrm{~m}^{3} / \mathrm{dnn}\right)$ un Daugavas upe $\left(63600 \mathrm{~m}^{3} / \mathrm{dnn}\right)$ kā virszemes ūdensgūtve. Šobrīd abu tipu ūdensgūtves neizmanto pat pusi no to maksimālās ražības, t. i., darbojas tehniski un ekonomiski neracionālā veidā.

Šāds stāvoklis ir sekas aplamai ticībai prognozei par Rīgas pilsētas ūdens patēriņu laikā no 1993. līdz 2010. gadam: 1993. gadā - 400 tūkst. $\mathrm{m}^{3} /$ dnn; 2010. gadā -340 tūkst. $\mathrm{m}^{3} /$ dnn. Šo prognozi izstrādāja Šveices kompānija $R W B \quad S A$ kā bezmaksas palīdzību pašvaldības uzṇēmumam Ūdensapgāde un kanalizācija (tagad SIA Rìgas ūdens). Stratēgija Rīgas ūdensapgādei bija izklāstīta dokumentā [2], ar kuru Latvijas pārstāvji tika iepazīstināti 1995. gada janvārī. Stratēgija rekomendēja vienlaicīgi modernizēt pazemes un Daugavas ūdensgūtvi tā, lai 2010. gadā tās Rīgai varētu dot $\sim 340$ tūkst. $\mathrm{m}^{3} / \mathrm{dnn}$ dzeramā ūdens. Latvija ieguldīja ievērojamus naudas līdzekḷus un darbu pazemes ūdensgūtvju kompleksa Baltezers, Zaķumuiža, Rembergi un Daugavas ūdens sagatavošanas stacijas modernizācijā, taču šobrīd reālais ūdens patēriņš ir aptuveni 2,8 reizes mazāks par 340 tūkst. $\mathrm{m}^{3} / \mathrm{dnn}$.

Rīgas pilsētai 2030. gadā būs nepieciešami aptuveni (120122) tūkst. $\mathrm{m}^{3}$ / dnn [1]. Šo ūdens daudzumu varētu iegūt tikai ar pazemes ūdensgūtvēm, jo Daugavas ūdens sagatavošana ir dārga, upe pakḷauta būtiskam piesārṇojuma riskam.

Rīgas Tehniskās universitātes (RTU) Vides modelēšanas centra (VMC) speciālisti 2016. gadā SIA Aqua-Brambis uzdevumā veica pazemes ūdensgūtvju kompleksa Baltezers, Zaķumuiža, Remberği datormodelēšanu, lai izpētītu š̄ kompleksa izmantošanas variantus hidroǵeoloǵijas aspektā (pazemes ūdens līmeṇu pazeminājuma piltuvju dati, laika apstākḷu ietekme, pazemes ūdens plūsmu aprēķins u. c.).

Rakstā nav analizēti ūdensgūtvju ekonomiskie parametri un ūdens sadales tīkla rekonstrukcijas jautājumi.

Pētījumu īstenošanai VMC izmantoja hidroǵeoloǵisko modeli (HM) [3] (skat. pielikumu), kurš darbojas licenzētas programmatūras Groundwater Vistas vidē [4]. Rezultātu noformēšanai izmantota sistēma SURFER [5].

\section{PAZEMES ŪDENSGŪTVJU IZMANTOŠANAS VARIANTI}

Bija jāmodelē pieci Rīgas pilsētas centralizētās ūdens apgādes varianti, kuru dati skatāmi I tabulā [1]. Kompleksā Baltezers, Zaķumuiža, Remberǵi darbojas piecas sifonu tipa ūdensgūtves: Baltezers, Baltezers1, Baltezers2, Remberǵi un Zaķumuiža. To izvietojums skatāms 1. attēlā. Sifoni ņem ūdeni no smilšu slāņa Q. Sifona ūdensgūtves darbības princips skaidrots grāmatā [6].

Sifona darbināšanai nav nepieciešami sūkṇi, un to ražīgumu var ērti regulēt. Sifona Baltezers un Baltezers2 ražības palielināšanai var izmantot pazemes ūdens resursu mākslīgo papildināšanu ar Mazā Baltezera ūdeni. Šim nolūkam paredzēti infiltrācijas baseini. Neviens no ūdensgūtvju variantiem neparedz infiltrācijas baseinu izmantošanu sifonu ražỉbas palielināšanai. Tāpēc I tabulā nav ietverts sifons Baltezers2, kura ražība ir būtiski atkarīga no ūdens mākslīgās infiltrācijas izmantošanas. Kompleksā darbojas ūdensgūtve Zaķumuiža D, kura izmanto dziḷumsūkṇus un ņem pazemes ūdeni no Devona D3gj2 ūdens horizonta. 
I TABULA

SIA AQUA-BRAMBIS PROGNOZĒTIE ŪDENSGŪTVJU RAŽİBAS VARIANTI

\begin{tabular}{|c|c|c|c|c|c|c|c|}
\hline \multirow{2}{*}{$\overline{\text { Ùdensgūtne }}$} & \multirow{2}{*}{$\begin{array}{c}\text { Ūdens } \\
\text { horizonts }\end{array}$} & \multirow[t]{2}{*}{$\overline{\mathbf{U S S}}$} & 1. variants & 2. variants & 3. variants & 4. variants & 5. variants \\
\hline & & & $\mathrm{m}^{3} / \mathrm{d}$ & $\mathrm{m}^{3} / \mathrm{d}$ & $\mathrm{m}^{3} / \mathrm{d}$ & $\mathrm{m}^{3} / \mathrm{d}$ & $\mathrm{m}^{3} / \mathrm{d}$ \\
\hline Baltezers & $\mathrm{Q}$ & Jā & 19000 & 19000 & 19000 & 19000 & 28000 \\
\hline Baltezers I & Q & $\mathrm{Jā}$ & 9600 & 9600 & 9600 & 9600 & 30000 \\
\hline Remberǵi & $\mathrm{Q}$ & $\mathrm{Ne \overline {e }}$ & 12000 & 17000 & 17000 & 17000 & 17000 \\
\hline Zaķumuiža Q & Q & $\mathrm{Ne}$ & 10000 & 17000 & 17000 & 17000 & 17000 \\
\hline Zaķumuiža D & $\mathrm{D}$ & $\mathrm{Ne}$ & 10500 & 28500 & 30000 & 30000 & 30000 \\
\hline Daugava PŪG & $\mathrm{D}$ & $\mathrm{Jā}$ & & & 30000 & & \\
\hline Baltezers I D & $\mathrm{D}$ & $\mathrm{Jā}$ & & & & 15000 & \\
\hline Rembergi D & $\mathrm{D}$ & $\mathrm{Jā}$ & & & & 15000 & \\
\hline Kopā PŪG & & & 61100 & 91100 & 122600 & 122600 & 122000 \\
\hline Daugava VŪG & $\mathbf{V} \overline{\mathbf{U}}$ & $\mathrm{Jā}$ & 63600 & 31800 & & & \\
\hline Pavisam & & & 124700 & 122900 & 122600 & 122600 & 122000 \\
\hline
\end{tabular}

Piezīmes:

ŪSS - ūdens sagatavošanas stacija;

Q - kvartārs;

D - devons (Gaujas horizonts);

PŪG - pazemes ūdensgūtnes;

VŪG - virszemes ūdensgūtnes.

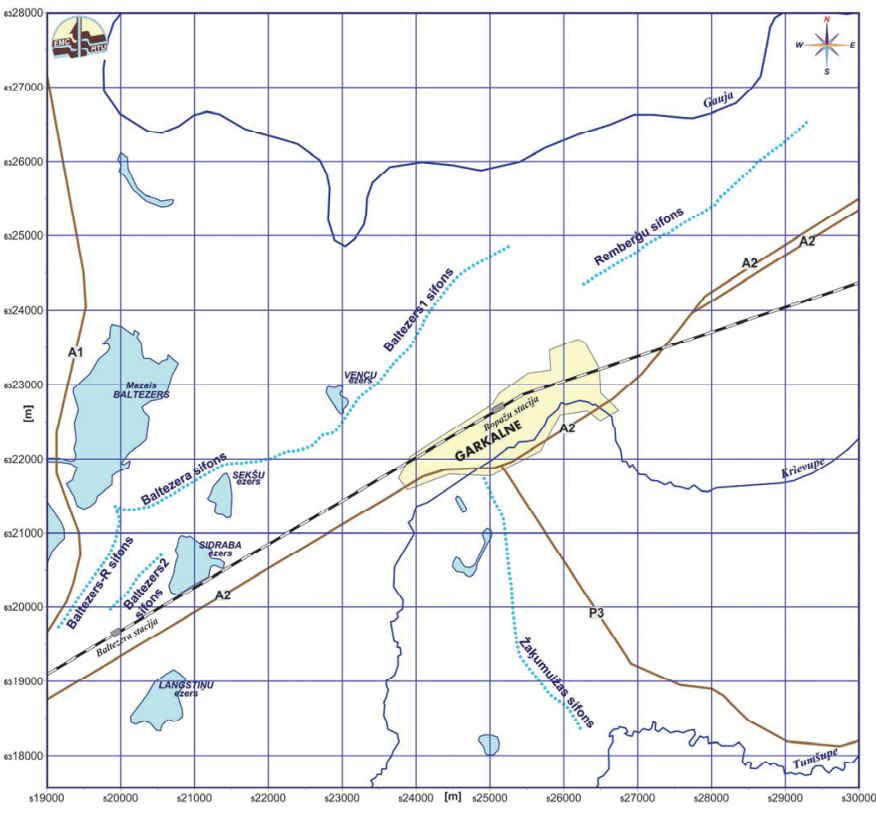

1. att. Ūdensgūtvju kompleksa sifonu izvietojums.

VMC bija jāanalizē variants Nr. 1, Nr. 2, Nr. 4, Nr. 5, jo 3. variants paredz jaunas ūdensgūtves Daugava $\mathrm{PU} G$ (30 tūkst. $\mathrm{m}^{3} / \mathrm{dnn}$ ) izveidošanu devona D3gj horizontā, Kekavas novadā, bet š̄ varianta sifona sistēmu ražība ir identiska variantam Nr. 2 un Nr. 4.

Pirmais variants atbilst 2015. gada apstākḷiem (61 100 tūkst. $\mathrm{m}^{3}$ / dnn no pazemes, 63600 tūkst. $\mathrm{m}^{3} /$ dnn no Daugavas).

Otrais variants paredz samazināt ūdens ņemšanu no Daugavas līdz 31800 tūkst. $\mathrm{m}^{3} /$ dnn, kas atbilst Daugavas ūdens sagatavošanas stacijas (ŪSS) minimāli pieḷaujamai jaudai. Zaķumuižas D ūdensgūtve (28 500 tūkst. $\mathrm{m}^{3} / \mathrm{dnn}$ ) gandrīz sasniedz savu maksimālo ražǐbu 30000 tūkst. $\mathrm{m}^{3}$ / dnn, pieaug sifonu Remberǵi un Zaķumuiža Q atdeve.

Varianti Nr. 3, Nr. 4, Nr. 5 neparedz Daugavas upes ūdens izmantošanu:

- 3. variants prasa veidot jaunu ūdensgūtvi Daugava PŪG;

- 4. variantā tiek īstenota papildus ūdens ieguve ar sūkņiem no devona D3gj1 horizonta ūdensgūtvēm Baltezers 1D un Remberği D;

- 5. variantā nelieto sifona tipa sistēmas, kuras nomaina urbumi ar dziḷumsūkniem Q horizontā. Viena urbuma ražība $\sim 1400 \mathrm{~m}^{3} / \mathrm{dnn}$.

Ūdensgūtvju variantiem noteikti šādi hidroǵeologiskie raksturojumi:

- depresijas piltuves forma un maksimālais dziḷums;

- mazūdens režīma ietekme uz šiem parametriem;

- pazemes ūdens plūsmu bilances.

\section{SIFONA ŪDENSGŪTVES DARBĪBAS NOTURĪBA}

Sifona ūdensgūtves darbības noturību pārbauda normāliem un mazūdens apstākḷiem. Kā noturības raksturošanas galveno elementu izmanto ūdensgūtves depresiju piltuves (ūdens līmeņu pazeminājuma) karti (piltuves forma un dziļums). Lai sifons darbotos stabili, tā piltuves dziḷums nedrīkst pārsniegt 6-7 metrus [6].

Depresijas piltuves karti iegūst, ja no HM aprēḳinātā netraucētā stāvokḷa ūdens līmeņu sadalījuma (2. att. Q horizonts) atskaita ūdensgūtves dinamisko ūdens līmeņu sadalījumu. Depresiju piltuve Q slānī 1. variantam, ja visi sifoni darbojas vienlaicīgi, skatāma 4. attēlā. 


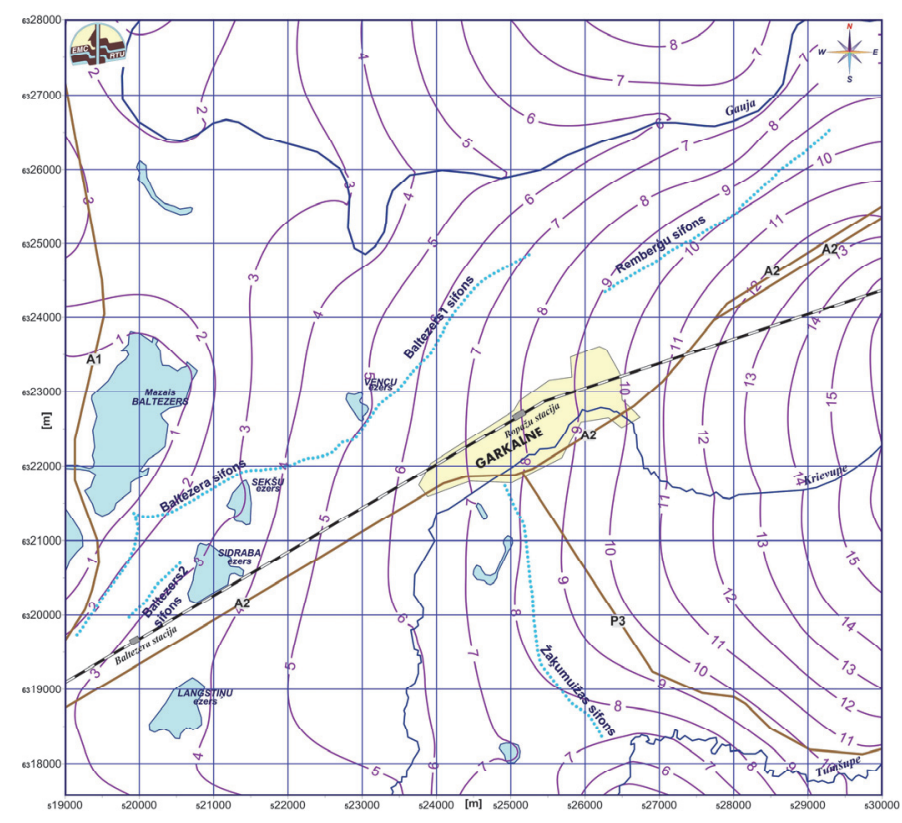

2. att. Netraucētā stāvokḷa ūdens līmeṇu sadalījums (m v.j.1.) horizontā Q.

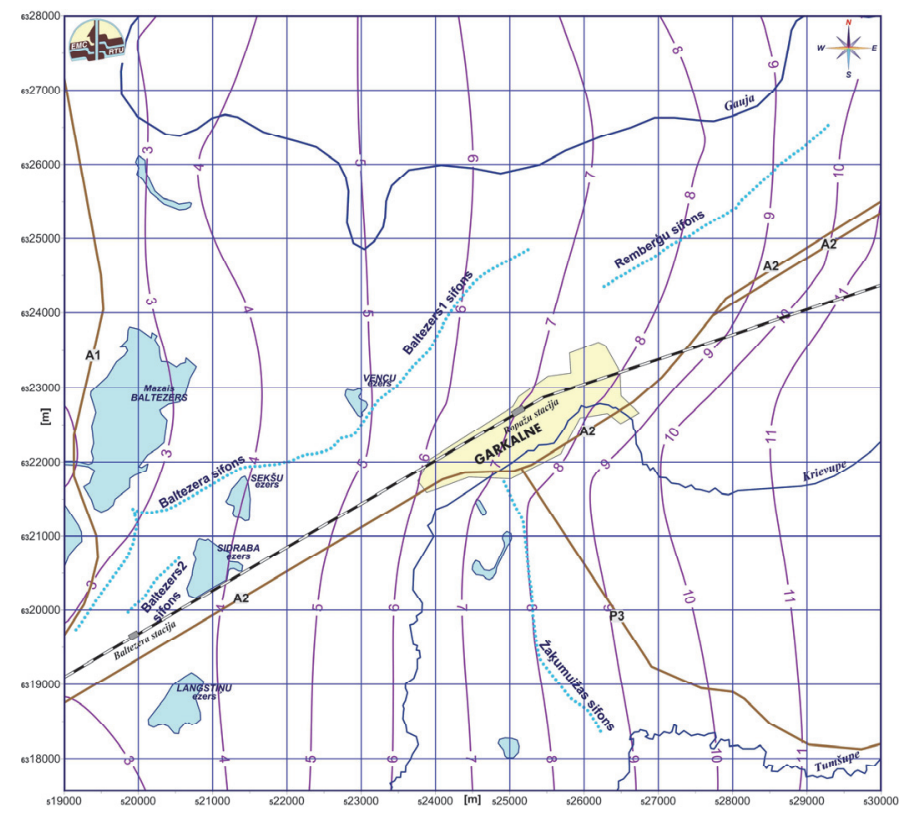

3. att. Netraucētā stāvokḷa ūdens līmeṇu sadalījums (m v.j.1.) horizontā D3gj2.

Sifonam var izmērīt tā lokālās depresijas piltuves dziḷumu (1,6 m - Baltezers R (rietumu daḷ); 2,2 m - Baltezers A (austrumu daḷa); 2,9 m - Baltezers 1; 3,0 m - Remberǵi; 2,5 m Zaḳumuiža).

Netraucētā stāvokḷa karte un depresiju piltuve 1. variantam D3gj2 horizontā skatāma 3. attēlā un 5. attēlā. Depresijas piltuves dziļums modelī Zaķumuižas D ūdensgūtvei ir 11,2 m, ja tās ražỉba ir $10500 \mathrm{~m}^{3} / \mathrm{dnn}$.

Depresiju piltuves 4. variantam kvartāra Q un devona D3gj1 horizontos skatāmas 6. attēlā un 7. attēlā. Devona horizontā dziḷurbumi ar ražīibu $1400 \mathrm{~m}^{3} / \mathrm{dnn}$ vienmērīgi izvietoti gar Baltezera 1 un Remberǵu sifonvadiem, īstenojot Baltezers 1D un Remberǵi D ūdensgūtvi.

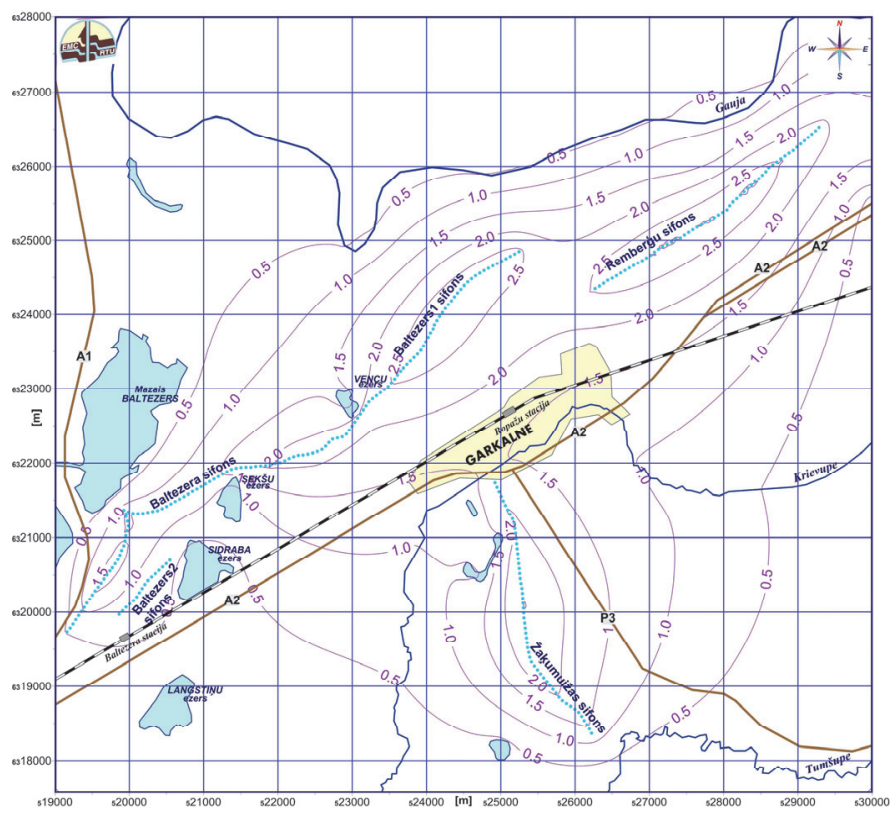

4. att. Depresiju piltuve (m) Q horizontā 1. variantam.

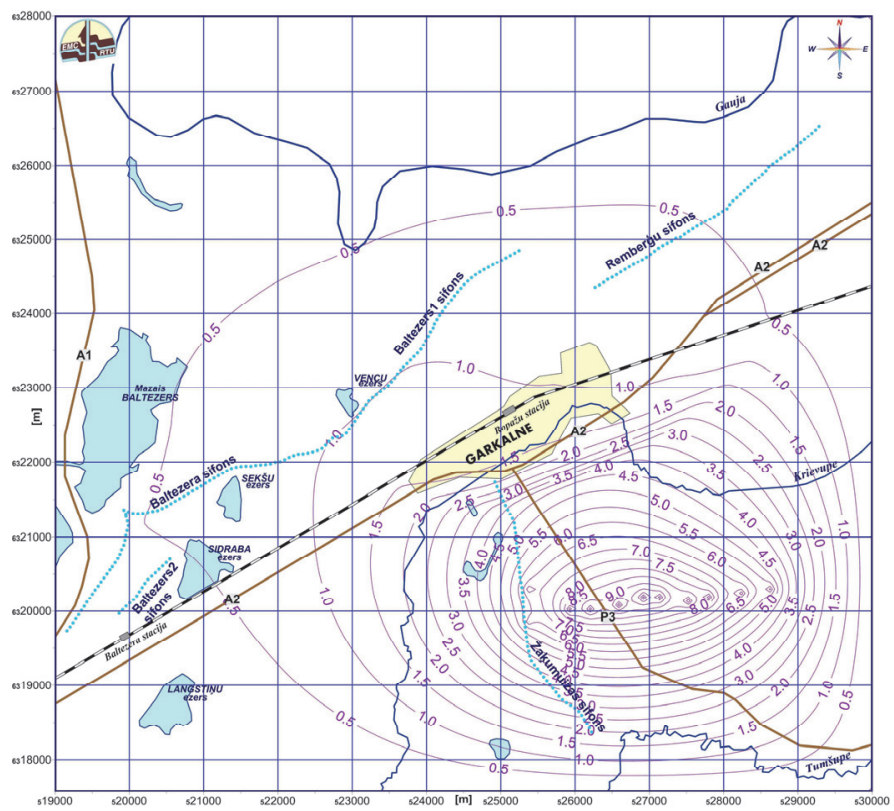

5. att. Depresiju piltuve (m) D3gj2 horizontā 1. variantam.

Depresiju piltuve 5. variantam kvartāra Q horizontā ir skatāma 8. attēlā. Ja salīdzina lokālās depresiju piltuves Zaķumuižas Q ūdensgūtvei (6. att., 8. att.), tad tās praktiski neatšķiras, jo abos variantos š̄is ūdensgūtves ražība (17 $\left.000 \mathrm{~m}^{3} / \mathrm{dnn}\right)$ nemainās. Piemēram, Zaķumuižas Q depresijas piltuves dziļums pieaug no 4,3 m līdz tikai 4,8 m. Šis pieaugums radies ūdensgūtves Baltezers un Baltezers 1 ietekmē, kuru ražības 5. variantā pieaugušas, attiecīgi (19 $000 \rightarrow$ $28000) \mathrm{m}^{3} / \mathrm{dnn} ;(9600 \rightarrow 30000) \mathrm{m}^{3} / \mathrm{dnn}$, salīdzinot ar 4. variantu (I tab.). Depresiju piltuvju attēli visiem analizētajiem ūdensgūtvju variantiem ir atrodami pārskatā [7]. 


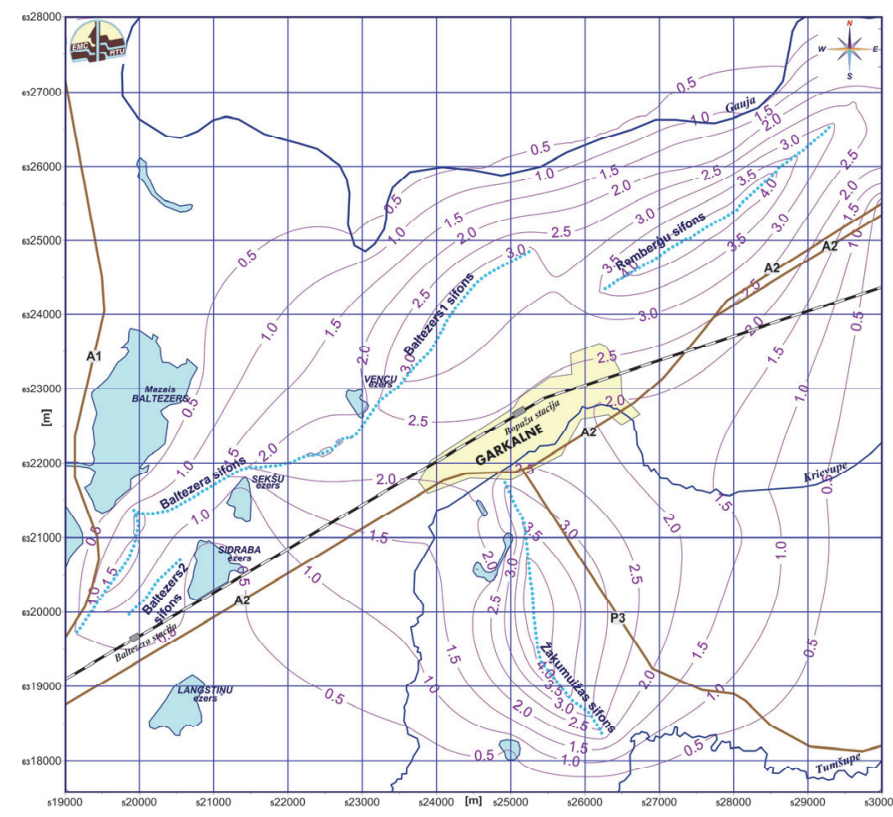

6. att. Depresiju piltuve (m) Q horizontā 4. variantam.

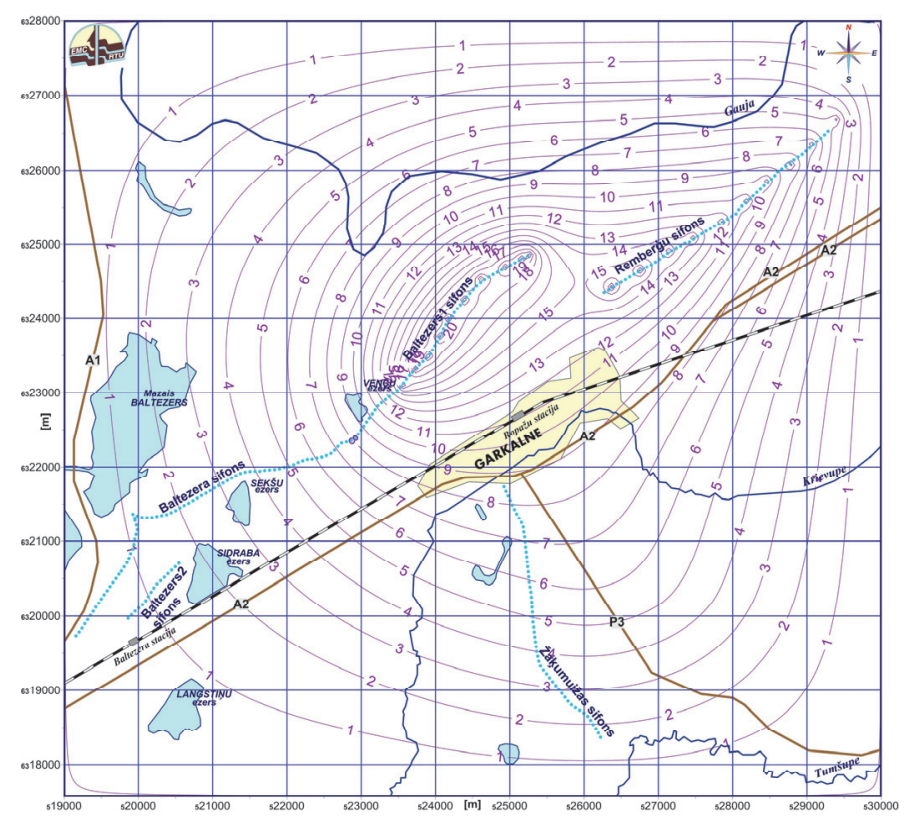

7. att. Depresiju piltuve (m) D3gj1 horizontā 4. variantam.

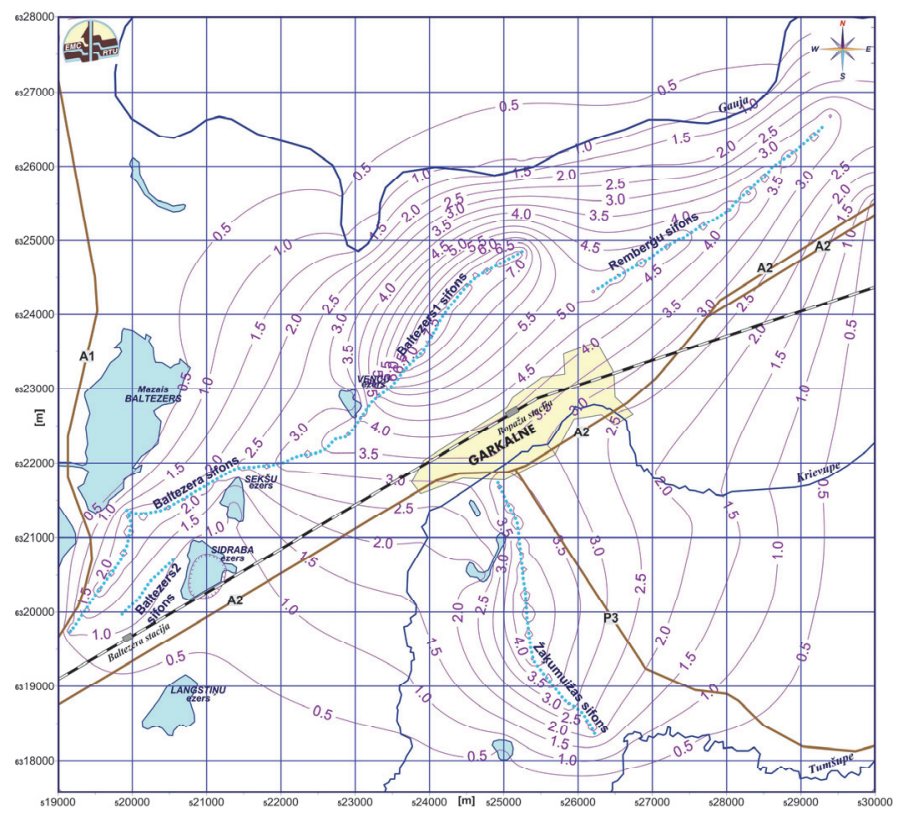

8. att. Depresiju piltuve (m) Q horizontā 5. variantam.

Dati par maksimālo depresijas piltuvju dziḷumu skatāmi II tabulā. Šeit ar indeksu "m" atzīmēts mazūdens režīms. Var konstatēt, ka pat mazūdens režīmā nevienam no sifona tipa ūdensgūtvēm depresijas piltuves dziḷums nepārsniedz 6 metrus, t. i., visos ražỉbas variantos sifoni darbosies stabili [6].

Datu kopums II tabulā liecina, ka:

- mazūdens režīmā depresiju piltuves dziḷums sifona ùdensgūtvēs pieaug par $(0,7-1,2) \mathrm{m}$;

- devona ūdensgūtves praktiski nav atkarīgas no mazūdens režīma;

- depresiju piltuvju dziḷumi ir proporcionāli ūdensgūtvju ražībai.

Reālie dziḷumsūkṇu radītie pazeminājumi to filtros ir lielāki par II tabulas datiem, kuri iegūti ar HM. Tomēr atšksirības no ar HM aprēḳinātās pazeminājuma piltuves ir tikai urbuma tuvumā (aplī, kura rādiuss ir 11 metri).

II TABULA

MAKSIMĀLAIS DEPRESIJAS PILTUVES DZIḶUMS ŪDENSGŪTN̦U IZMANTOŠANAS VARIANTIEM

\begin{tabular}{|l|l|l|l|l|l|l|l|l|}
\hline \multirow{2}{*}{ Ūdensgūtve } & \multicolumn{2}{|l}{ Ūdensgūtnu izmantošanas varianti (m-mazūdens režīms) } \\
\cline { 2 - 10 } & 1 & $1_{\mathrm{m}}$ & 2 & $2_{\mathrm{m}}$ & 4 & $4_{\mathrm{m}}$ & 5 & $5_{\mathrm{m}}$ \\
\hline Baltezers R & 1,60 & 1,90 & 1,7 & 2,0 & 1,7 & 2,0 & 2,6 & 2,9 \\
\hline Baltezers A & 2,20 & 2,90 & 2,4 & 3,2 & 2,4 & 3,3 & 3,9 & 5,1 \\
\hline Baltezers 1 & 2,90 & 3,90 & 3,2 & 4,3 & 3,4 & 4,6 & 7,8 & 2,4 \\
\hline Remberǵi & 3,00 & 4,20 & 4,0 & 5,5 & 4,3 & 5,7 & 5,3 & 6,8 \\
\hline Zaķumuiža Q & 2,50 & 3,50 & 4,2 & 5,5 & 4,3 & 5,6 & 4,8 & 6,1 \\
\hline Zak̦umuiža D3gj2 & 11,20 & 11,50 & 30,6 & 30,8 & 32,8 & 33,1 & 32,8 & 32,6 \\
\hline Devons D3gj1 & 0 & 0 & 0 & 0 & 22,5 & 22,8 & 0 & 0 \\
\hline
\end{tabular}


Urbumu papildu pazeminājuma $\Delta S$ aprēḳinu dod izteiksme [8]:

$$
\Delta S=\frac{q}{2 \pi T}(\ln (0,2 h / r)+\xi),
$$

kur $q$ - urbuma ražība, $\mathrm{m}^{3} / \mathrm{dnn} ; T$ - ūdens vadāmība, $\mathrm{m}^{2} / \mathrm{dnn}$; $h$ - režǵa solis HM; $r$ - urbuma filtra rādiuss, m; $\xi$ - urbuma hidrauliskā pretestība. Formulā (1) izmantotā izteiksme $0,2=r_{\text {ekv }}$ HM režğa šūnas ekvivalentajam rādiusam $r_{\text {ekv }}$ iegūta darbā [9].

Ja urbumiem D3gj1 slānī $q=1400 \mathrm{~m}^{3} / \mathrm{dnn}, \quad T=$ $300 \mathrm{~m}^{2} / \mathrm{dnn}, h=55 \mathrm{~m} ; r=0,2 \mathrm{~m}, \xi=4,0, \operatorname{tad} \Delta S=6,0 \mathrm{~m}$.

Ja sifona urbumiem $q \sim 150 \mathrm{~m}^{3} / \mathrm{dnn}$ un vidējā ūdensvadāmība Q slānim $T=700 \mathrm{~m}^{2} / \mathrm{dnn}$, tad formula (1) dod $\Delta S \sim 0,3 \mathrm{~m}$, t. i., sifonam papildu depresijas piltuves padziļinājums ir niecīgs.

Piektajā variantā sifoni kvartāra Q horizontā aizvietoti ar dziḷumsūkṇiem, kuru ražība $1400 \mathrm{~m}^{3} / \mathrm{dnn}$. Tad iespējams ūdensgūtves ražību nodrošināt ar būtiski mazāku urbumu skaitu (III tab.), praktiski nepalielinot depresiju piltuvju dziļumu, salīdzinot ar sifonu ūdensgūtvju izmantošanas variantiem.
III TABULA

SALĪDZINOŠIE DATI PAR DZIḶUMSŪKN̦U UN SIFONU SISTĒMU URBUMIEM 5. VARIANTAM

\begin{tabular}{|c|c|c|c|c|}
\hline \multirow{2}{*}{ Ūdensgūtve } & \multicolumn{2}{|c|}{ Dzilurbumi } & \multicolumn{2}{c|}{ Sifona urbumi } \\
\cline { 2 - 5 } & Skaits & $\begin{array}{c}\text { Vidējais } \\
\text { attālums, } \mathrm{m}\end{array}$ & Skaits & $\begin{array}{c}\text { Vidējais } \\
\text { attālums, } \mathrm{m}\end{array}$ \\
\hline Baltezers A & 20 & $\sim 300$ & 121 & $\sim 50$ \\
\hline Baltezers 1 & 20 & $\sim 150$ & 72 & $\sim 38$ \\
\hline Remberği & 12 & $\sim 400$ & 55 & $\sim 78$ \\
\hline Zaķumuiža & 12 & $\sim 300$ & 90 & $\sim 42$ \\
\hline
\end{tabular}

\section{PAZEMES ŪDENS PLŪSMU BILANCE}

Ar sistēmas GV instrumentiem var iegūt pazemes ūdens plūsmu bilances, kuras ietver visus HM slāṇus Q1, Q2, D3gj2, D3gj1 (2p. att. pielikumā). Bilances netraucētam stāvoklim 1. un 5. variantiem skatāmas IV tabulā. Dati par bilancēm citiem ūdensgūtvju variantiem ir doti pārskatā [7].

Bilances tabulas slānī Q1 plūsma caur slāṇa augšu atbilst atmosfēras nokrišnu nodrošinātai infiltrācijai. Bilances tabula parāda, kā šī plūsma baro upes un ezerus, urbumus, plūsmu caur modeḷa apgabala sānu robežām.

IV TABULA

PAZEMES PLŪSMU BILANCE (TŪKST. M³ / DNN) ŪDENSGŪTVJU IZMANTOŠANAS VARIANTIEM

\begin{tabular}{|c|c|c|c|c|c|c|c|}
\hline Slāņi & $\begin{array}{c}\text { Caur slāņa } \\
\text { augšu }\end{array}$ & $\begin{array}{c}\text { Caur slāņa } \\
\text { apakšu }\end{array}$ & $\begin{array}{c}\text { Rezultējošã } \\
(2+3)\end{array}$ & Upes & Ezeri & Robežas & Urbumi \\
\hline 1 & 2 & 3 & 4 & 5 & 6 & 7 & 8 \\
\hline \multicolumn{8}{|c|}{ Netraucētais stāvoklis } \\
\hline Q1 & 55,34 & 0,78 & 56,12 & $-33,89$ & $-22,04$ & $-0,19$ & 0 \\
\hline Q2 & $-0,78$ & 0,28 & $-0,50$ & 0 & 0 & 0,50 & 0 \\
\hline D3gj2 & $-0,28$ & $-1,16$ & $-1,44$ & 0 & 0 & 1,44 & 0 \\
\hline D3gj1 & 1,16 & 0 & 1,16 & 0 & 0 & $-1,16$ & 0 \\
\hline \multicolumn{3}{|c|}{ Kopā } & 55,34 & $-33,89$ & $-22,04$ & 0,59 & 0 \\
\hline \multicolumn{8}{|c|}{ 1. variants } \\
\hline Q1 & 68,17 & $-45,70$ & 22,47 & $-22,43$ & $-4,99$ & 4.95 & 0 \\
\hline Q2 & 45,70 & $-0,77$ & 44,93 & 0 & 0 & 5.67 & -50.60 \\
\hline D3gj2 & 0,77 & 1,36 & 2,13 & 0 & 0 & 8.37 & -10.50 \\
\hline D3gj1 & $-1,36$ & 0 & $-1,36$ & 0 & 0 & 1.36 & 0 \\
\hline \multicolumn{3}{|c|}{ Kopā } & 68,17 & $-22,43$ & $-4,99$ & 20,35 & $-61,10$ \\
\hline \multicolumn{8}{|c|}{ 1m. variants } \\
\hline Q1 & 38,34 & $-38,61$ & 0,27 & $-14,46$ & 3,06 & 11.13 & 0 \\
\hline Q2 & 38,61 & 0,29 & 38,90 & 0 & 0 & 11.70 & -50.60 \\
\hline D3gj2 & $-0,29$ & 1,77 & 1,48 & 0 & 0 & 9.02 & -10.50 \\
\hline D3gj1 & $-1,77$ & 0 & $-1,77$ & 0 & 0 & 1.77 & 0 \\
\hline \multicolumn{3}{|c|}{ Kopā } & 38,34 & $-14,46$ & 3,06 & 34,17 & $-61,10$ \\
\hline \multicolumn{8}{|c|}{ 5. variants } \\
\hline Q1 & 80,72 & $-85,93$ & $-5,21$ & $-10,98$ & 7,51 & 8.68 & 0 \\
\hline Q2 & 3,45 & $-3,45$ & 82,48 & 0 & 0 & 9.52 & -92.00 \\
\hline D3gj2 & $-5,10$ & 5,10 & 8,55 & 0 & 0 & 21.45 & -30.00 \\
\hline D3gj1 & & 0 & $-5,10$ & 0 & 0 & 5.10 & 0 \\
\hline \multicolumn{3}{|c|}{ Kopā } & 80,72 & $-10,98$ & 7,51 & 44,75 & $-122,00$ \\
\hline \multicolumn{8}{|c|}{$5 \mathrm{~m}$. variants } \\
\hline Q1 & 46,29 & $-77,52$ & $-31,23$ & $-2,73$ & 17,94 & 16.02 & 0 \\
\hline Q2 & 77,52 & $-1,98$ & 75,54 & 0 & 0 & 16.46 & -92 \\
\hline D3gj2 & 1,98 & 5,69 & 7,67 & 0 & 0 & 22.33 & -30 \\
\hline D3gj1 & $-5,69$ & 0 & $-5,69$ & 0 & 0 & 5.69 & 0 \\
\hline \multicolumn{3}{|c|}{ Kopāā } & 46,29 & $-2,73$ & 17,94 & 60,50 & $-122,00$ \\
\hline
\end{tabular}


Netraucētajā stāvoklī praktiski nav robežu plūsmu, un upju un ezeru pazemes pietece sasniedz maksimālās vērtības 33,83 tūkst. $\mathrm{m}^{3} /$ dnn un $-22,04$ tūkst. $\mathrm{m}^{3} / \mathrm{dnn}$, kas praktiski atbilst infiltrācijas plūsmai $\left(55,34\right.$ tūkst. $\left.\mathrm{m}^{3} / \mathrm{dnn}\right)$. Plūsma 55,34 tūkst. $\mathrm{m}^{3} / \mathrm{dnn}$ atbilst gada vidējai infiltrācijai $55,34 \times 10^{3} \times 365 \times 10^{3} /(11000 \times 10450)=175,7 \mathrm{~mm}$ gadā modeḷa teritorijā, t. i., $1000 \mathrm{~m}^{3} / \mathrm{dnn}=3,17 \mathrm{~mm}$ gadā. $\breve{S}_{\overline{1}}$ sakritība lauj novērtēt infiltrāciju tai raksturīgā veidā (mm gadā) arī IV tabulā. Ūdensgūtvju 1. un 5. variants atbilst mūsdienu un forsētai ražỉbai kvartāra un devona horizontos. Šī iemesla dēḷ šie varianti iekḷauti IV tabulā.

Bilances tabula l̦auj izsekot plūsmu izmaiņām ne tikai atsevišķos ūdens slāṇos bet arī vispārīgajam pazemes plūsmu sadalījumam, kuram atbilst tabulas datu kopsumma katrā kolonā. Piemēram, salīdzinot ar netraucēto stāvokli, 1. variantā ir pieaugusi infiltrācijas plūsma $(55,34 \rightarrow 68,17)$ tūkst. $\mathrm{m}^{3} / \mathrm{dnn}$ un plūsma caur robežu $(0,59 \rightarrow 20,35)$ tūkst. $\mathrm{m}^{3} /$ dnn. Samazinājusies plūsma upēs $(33,89 \rightarrow 22,43)$ tūkst. $\mathrm{m}^{3} /$ dnn un ezeros $(22,04 \rightarrow 4,99)$ tūkst. $\mathrm{m}^{3} / \mathrm{dnn}$. Šādā veidā hidroǵeoloǵiskā vide ir nodrošinājusi urbumu ražības 50,60 un 10,50 tūkst. $\mathrm{m}^{3} /$ dnn Q un devona horizontos.

Mazūdens $1 \mathrm{~m}$. variantā, salīdzinot ar normālo 1. variantu, samazinās infiltrācija $(68,17 \rightarrow 38,34)$ tūkst. $\mathrm{m}^{3} / \mathrm{dnn}$ un upju plūsma $(22,43 \rightarrow 14,46)$ tūkst. $\mathrm{m}^{3} / \mathrm{dnn}$; palielinās barojošā plūsma caur robežu $(20,35 \rightarrow 34,14)$ tūkst. $\mathrm{m}^{3} / \mathrm{dnn}$; ezeru plūsma kḷūst pozitīva $(-4,99 \rightarrow 3,06)$ tūkst. $\mathrm{m}^{3} / \mathrm{dnn}$.

Forsētajā 5. variantā ar dzilumsūkniem, salīdzinot ar 1. variantu, ražība $Q$ un devona slān,os pieaug $(50,60 \rightarrow 92,00)$ tūkst. $\mathrm{m}^{3} /$ dnn un $(10,5 \rightarrow 30,0)$ tūkst. $\mathrm{m}^{3} / \mathrm{dnn}$; aug kopējā ražība $(61,10 \rightarrow 122,0)$ tūkst. $\mathrm{m}^{3} / \mathrm{dnn}$. No IV tabulas var secināt, ka arī 5. variantā urbumu kopējās ražības pieaugums nodrošina galvenokārt infiltrācijas un robežu plūsma.

Devona horizontos urbumu ražību nodrošina galvenokārt barojošā plūsma caur HM robežu. Infiltrācijas plūsmai te ir maza loma.

Šajā pētījumā nav analizētas atsevišḳu ūdensgūtvju (Baltezers, Baltezers1, Remberg̣i, Zaķumuiža) lokālās bilances, bet tikai bilance HM apgabalā, kura l̦auj noskaidrot, kā tiek nodrošināta pazemes ūdensgūtvju ražība kompleksā Baltezers, Zaķumuiža, Rembergí.

\section{SECINĀJUMI}

Datormodelēšanas rezultāti apstiprina, ka hidroǵeolog̣ijas aspektos ūdensgūtvju kompleksā Baltezers, Zaḳumuiža, Remberğ $i$ var īstenot visus piecus SIA $A Q U A-B R A M B I S$ ieteiktos ūdensgūtvju variantus. Ir iespējams sifonu ūdensgūtves kvartāra smilšu slānī nomainīt ar dziḷumsūkṇiem. Šì nomaiņa būtiski samazinātu ekspluatācijas urbumu skaitu. Nav sagaidāma tāda depresijas piltuvju dziļuma palielināšanās, kura būtiski atšķirtos no sifona ūdensgūtvju piltuvēm.

\section{PIELIKUMS HIDROG̣EOLOGISKAIS MODELIS}

Pazemes ūdensgūtvju kompleksa HM imitē gada vidējos ilggadīgos hidroǵeoloǵiskos apstākḷus un ir stacionārs. HM novietojums Rīgas apkārtnē ir skatāms 1p. attēlā. Modeḷa izmēri ir $11000 \mathrm{~m} \times 10450 \mathrm{~m}$, un tā plaknes režğa solis $h=$ $55 \mathrm{~m}$.

HM darbojas licenzētas programmatūras GV vidē.

HM vertikālā shematizācija ir skatāma 2p. attēlā.

Kvartāra sistēma pārstāvēta ar četriem slāņiem, kuriem atbilst aerācijas zona aer (formāls sprostslānis), smilšu slāṇi Q1 un Q2, morēna gQ kā sprostslānis. Slānim Q1 piesaistīiti upes un ezeri, bet slān̄̄ Q2 realizē kvartāra sistēmas ekspluatācijas urbumus.

Devona sistēmu modelī pārstāv Gaujas svītas smilšakmens ūdens horizonti D3gj2, D3gj1 un tos atdalošais sprostslānis D3gj1z. Slāņa D3gj1 apakša ir ūdens necaurlaidīga.

Robežnoteikumi horizontiem ūdens līmeṇu veidā uzdoti uz modeḷa robežas kontūra. Model̦a pirmajā slānī rel uzdots zemes virsmas reljefs kā ūdens līmeņa tipa robežnoteikums.

Ūdensgūtņu ražības variantu analīzei mazūdens režīmam (50 \% no normāliem apstākḷiem) ilgstošam laikam iegūst, ja uz pusi samazina aer zonas hidraulisko vadāmību. Šāds režīms ir Latvijā maz varbūtīgs, un tāpēc tas īsteno ūdensgūtvju darbības noturības pārbaudi ekstremālos apstākḷ,os, kas raksturīga tikai būtiskām klimata izmain̄ām.

Detalizētāks HM apraksts dots pārskatā [3].

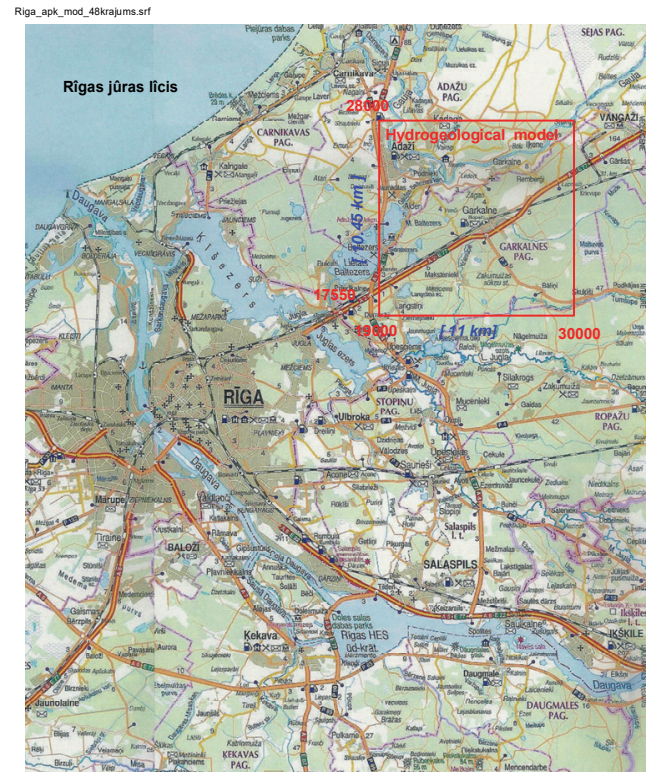

1p. att. Hidroǵeologiskā modeḷa novietojums Rīgas apkārtnē.

\begin{tabular}{|c|c|c|c|}
\hline Slāņa tips & $\begin{array}{l}\text { Slāṇa } \\
\text { nosaukums }\end{array}$ & $\begin{array}{l}\text { G̦eologiskais kods } \\
\text { modelī }\end{array}$ & $\begin{array}{l}\text { Model̦a sekcijas } \\
\text { numurs un tips }\end{array}$ \\
\hline & Reljefs & relh & $\begin{array}{l}\text { 1. (robežnoteikums) } \\
\text { (zemes virsmas } \\
\text { reljefa karte) }\end{array}$ \\
\hline & & aer & 2. $(z)$ \\
\hline & & $Q 1$ & 3. $(x y)$ \\
\hline & & $Q 2$ & 4. $(x y)$ \\
\hline & & $g Q$ & 5. $(z)$ \\
\hline & Otrā Gauja & $D_{3} g j 2$ & $6(x y)$ \\
\hline & Pirmā Gauja & $D_{3} g j 1 z$ & 7. $(z)$ \\
\hline & & $D_{3} g j 1$ & 8. $(x y)$ \\
\hline
\end{tabular}

2p. att. Modeḷa vertikālā shematizācija. 


\section{LITERATŪRAS SARAKSTS}

[1] A. Spalviñš, Rīgas pilsētas ūdensgūtnuu izvērtējums un ūdensgūtṇu optimizācijas plāna izstrāde. Noslēguma ziņojums. 2. redakcija, Riga: SIA Aqua-Brambis, 2016. (in Latvian)

[2] J.-L. Walther, "Riga Water Supply Strategy" presented at workshop in Riga, January 19, 1995, $30 \mathrm{p}$.

[3] A. Spalviňš, Baltezera, Remberǵu un Zakumuižas ūdensgūtvju kompleksa optimizācija un piesārṇojumu migrācijas kait̄̄guma prognozēěana ar skaitliskās modelēšanas līdzekḷiem, Atskaite IZM-RTU projektam Nr. U7115, Rīga -decembris, 2006. (in Latvian)

[4] Environmental Simulations, Inc. "Groundwater Vistas. Version 6, Guide to using," 2011.

[5] Golden Software, Inc., "SURFER-10 (2012) User's Guide".

[6] V. Skārds, Ūdens apgāde un kanalizācija, Rīga: Liesma, 1970, 309 lpp. (in Latvian)

[7] A. Spalvin̦š, Rīgas pilsētas pazemes üdensgūtnu ražỉbas variantu izvērtējums, pārskats, Rīga: RTU, jūnijs, 2016. (in Latvian)

[8] F. M. Bočever, Proektirovanie vodozaborov podzemnyh vod. Moskva: Strojizdat, 1976, p. 291. (in Russian)

[9] M. M. Maksimov and L. P. Rybickaja, Matematičeskoe modelirovanie processov razrabotki neftjanyh mestoroždenij. Moskva: Nedra, 1976, p. 264. (in Russian)

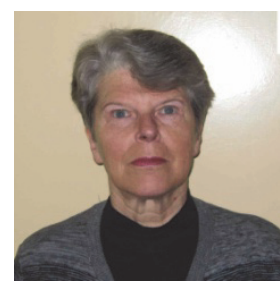

Inta Lāce was born in Latvia. In 1971, she graduated from Riga Polytechnical Institute (Riga Technical University since 1990) as a Computer Engineer. In 1995, she received the Master's degree in Applied Computer Science. Since 1991, she is a Researcher at the Environment Modelling Centre of the Faculty of Computer Science and Information Technology, RTU.

E-mail: inta.lace@yahoo.com

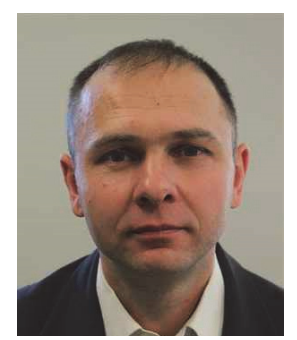

Kaspars Krauklis received the Master's degree in Computer Systems from Riga Technical University in 2007 and the Certificate in Teaching of Engineering Sciences from the Institute of Humanities of RTU in 2005. He is a Researcher at the Environment Modelling Centre of RTU.

E-mail: Kaspars.Krauklis@gmail.com

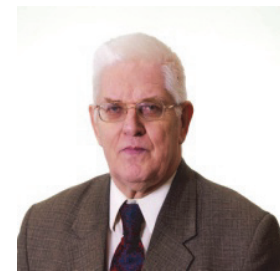

Aivars Spalvin̨š was born in Latvia. In 1963, he graduated from the Riga Polytechnical Institute (Riga Technical University since 1990) as a Computer Engineer. $\mathrm{He}$ is $\mathrm{Head}$ of the Environment Modelling Centre of RTU. His research interests include computer modelling of groundwater flows and migration of contaminants. E-mail: Aivars.Spalvins@rtu.lv

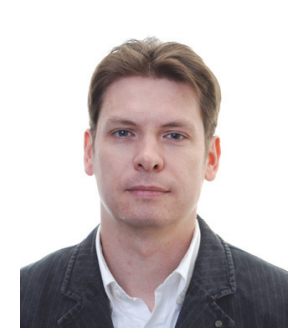

Juris Laicāns received the M. Sc. degree in Water Technologies from Riga Technical University (RTU) and the M. Sc. degree in Sustainable Infrastructure and Environmental Engineering from Royal Institute of Technologies (KTH), Stockholm. Currently he is a Senior Engineer in Latvian water engineering consultancy company "Aqua Brambis" SIA. His graduation thesis at RTU was on the problems of drinking water quality in the water supply system of Jurmala city in Latvia. His graduation thesis at KTH was on the treatment processes in Liepaja wastewater treatment plant (Latvia), including its computer simulation using software EFOR. During 18 years of his engineering career Juris has participated in numerous projects focussing on the development of water supply and sewerage systems in a number of towns and urban areas in Latvia.

E-mail: jla@aqua-brambis.lv

Evaluation of Hydrogeological Quality of Various Implementations of Riga City Water Supply System

Inta Lāce ${ }^{1}$, Kaspars Krauklis ${ }^{2}$, Aivars Spalviñ̌̌ $\check{3}^{3}$, Juris Laicāns ${ }^{4}$

${ }^{1-3}$ Riga Technical University, Latvia,${ }^{4}$ Ltd "Aqua-Brambis"

Drinking water for Riga city is provided by the groundwater well field "Baltezers, Zakumuiza, Rembergi" and by the Daugava river as a surface water source. Presently (2016), it amounts to 122 thous. $\mathrm{m}^{3} /$ day and both sources do not exploit even half of their power. Therefore, in future it seems reasonable to use only groundwater, because the river water is of low quality and its treatment is expensive. Scientists of Riga Technical University by using hydrogeological model of the well field "Baltezers, Zakumuiza, Rembergi" proved that its capacity covers the demand for $120-122$ thous. $\mathrm{m}^{3} /$ day of drinking water in Riga until 2030 . Therefore, it is possible not to exploit the Daugava river as the water source. The research was done as to the request of the company "Aqua-Brambis". The company asked to evaluate hydrogeological properties of several versions of water supply of Riga city. It was necessary to check the stability of syphon type systems that extract the groundwater for the city under the conditions of their increased productivity. It was also proved that the syphons may be replaced by a pumping station. Then the number of exploitation wells considerably decreases. The impact of expenses related to reconstruction of the wellfield and the water distribution network was not considered. The publication may be of interest for the specialists dealing with problems of water supply for large cities.

Keywords - hydrogeological model, groundwater well fields, syphon, pumping of groundwater. 